\title{
EFFECT OF REMIFENTANIL VERSUS LIDOCAINE ON THE HAEMODYNAMIC RESPONSE TO OROTRACHEAL INTUBATION
}

\author{
By \\ Mona A. Hasheesh \\ From \\ Lecturer of anaesthesia Mansoura University
}

\begin{abstract}
We have examined the effect of remifentanil on the haemodynamic response to orotracheal intubation in comparison to lidocaine in randomized double blind study. We studied 30 patients allocated to one of three groups, 10 patients each, to receive the following immediately before induction of anaesthesia: saline only in the 1 st group, lidocaine $2 \mathrm{mg} / \mathrm{kg}$ to the $2^{\text {nd }}$ group and remifentanil $1 \mathrm{ug} / \mathrm{kg}$ bolus over 30 seconds to the 3 rd group, then anaesthesia was induced with thiopentone, vecronium and maintained with $60 \% \mathrm{~N} 2 \mathrm{O}$ in oxygen and halothane $0.5 \%$, the trachea was intubated under direct lasyngeoscopy 3 $\mathrm{min}$. after induction of anaesthesia.
\end{abstract}

Arterial blood pressure and heart rate were measured immediately before induction of anaesthesia and then every minute from the start of in- duction until 5 minutes after intubation. Remifentanil was found to be effectively attenuating the perssor response to tracheal intubation in contrast to lidocaine which was found to be ineffective to attenuate this response.

\section{INTRODUCTION}

The presser response to tracheal intubation, resulting in tachycardia and hypertension, is well described (1), plasma concentrations of catecholamine are increased (2) and there may be associated myocardial ischemia (3). This response is undesirable, especially in patients with cardiovascular or intracranial disease. Topical and intravenous lidocaine, opioids, inhaled anaesthetics, or adrenergic blockers are used in an attempt to blunt these potentially adverse haemodynamic responses. Lidocaine has been found to be inconsistently effecMANSOURA MEDICAL JOURNAL 
tive (4). inhalation anaesthesia is used but requires deep levels, may delay recovery after short operation, and can cause cardiovascular depression (5). Low doses of narcotics are effective, but may cause respiratory depression or rigidity, or they may prolong recovery time (6).

Remifentanil is a new opioid agent that is structurally unique. An ester bond renders it subject to rapid hydrolysis by non-specific blood and tissue esterases and thus it has short half life (7). Speed of onset of effect is rapid (1-2 $\mathrm{min})$ and similar to that of alfentanil (8). Therefore, remifentanil may be appropriate for attenuation of the pressor responses to brief but noxious stimuli. The aim of this study is to assess the effect of remifentanil versus lidocaine on changes in heart rate and arterial blood pressure after intubation.

\section{PATIENTS AND METHOD}

30 patients, ASA physical status I,II aged 18-48 years, scheduled for elective surgery were the subject of this study, patients with arterioventricular conduction block greater than first degree, congestive heart failure, cardiac arrhythmias, asthma or use of B-blokers within $24 \mathrm{~h}$ preceding sur- gery were excluded. Patients were classified into 3 groups 10 patients each; to receive the following in a radomized, double blind manner: saline only; lidocaine $2 \mathrm{mg} / \mathrm{kg}$; remifentanil 1 $\mathrm{ug} / \mathrm{kg}$ bolus given over 30 seconds. All treatments were given immediately before induction of anaesthesia. After preoxygenation anaesthesia was induced with thiopentone sodium $5 \mathrm{mg} /$ $\mathrm{kg}$, tracheal intubation was facilitated by vecuronium $0.1 \mathrm{mg} / \mathrm{kg}$ under direct laryngoscopy 3 minutes after induction of anaesthesia, then anaesthesia was maintained using $0.5 \%$ halothane with $60 \%$ nitrous oxide in oxygen, the lungs were ventilated mechanicaly (tidal volume $10 \mathrm{ml} / \mathrm{kg}$, target end tidal carbon dioxide $30-35$ $\mathrm{mm} \mathrm{Hg}$ ).

Basal arterial blood pressure was measured non invasively using an automatic oscillometric device (Datex cardiocap), and heart rate recorded from the ECG trace. Observation of mean arterial pressure and heart rate were recorded every minute from the start of induction to $5 \mathrm{~min}$. after intubation. Hypotension was treated with ephedrine $5 \mathrm{mg}$ increments I.V., bradycardia was treated with atropine 300 $\mu \mathrm{g}$ increments I.V. Statistical analysis was performed using student $-T$ test. 


\section{RESULTS}

The three groups were comparable in age and body weight. Heart rate was significantly decreased in remifentanil group after induction of anaesthesia and remained lower after tracheal intubation when compared with basal values and non remifentanil groups $(p<0.01)$ and $(p<0.001)$ respectively. Heart rate showed significant increase after intubation (at 1,2,3 min.) in non remifentanil groups (saline and lidocaine) as compared with basal values $(p<0.01)$ (Table 1).

There was significant decrease in mean arterial blood pressure after induction of anaesthesia and remained lower after intubation as compared with basal values andnon remifentanil groups $(p<0.01)$.

Mean blood pressure was significantly increased in non remifentanil groups after laryngeoscopy and intubation (at 1,2 minutes) as compared to basal values $(P<0.01)$. (Table 2)

Five patients in remifentanil group had bradycardia or hypotention or both requiring medications. 
312 EFFECT OF REMIFENTANIL VERSUS LIDOCAINE etc...

Table (1) : heart rate in saline, lidocaine and remifentanil groups from induction to 5 minutes after intubation (values are in mean).

\begin{tabular}{|c|c|c|c|}
\hline Time & Saline & Lidocaine & Remifentanil \\
\hline 0 & 85 & 89 & 89 \\
\hline (induction)1 & 87.5 & 86.5 & $70^{*} \bullet$ \\
\hline 2 & 87.5 & 86 & $68^{*} \bullet$ \\
\hline 3 & 87 & 86 & $62.5^{*} \bullet$ \\
\hline (intubation)1 & $110 \#$ & $102 \#$ & $65^{*} \bullet$ \\
\hline 2 & $108 \#$ & $100 \#$ & $62^{*} \bullet$ \\
\hline 3 & $103 \#$ & $98.5 \#$ & $60^{*} \bullet$ \\
\hline 4 & 93 & 90 & $59^{*} \bullet$ \\
\hline 5 & 90 & 82 & $58^{*} \bullet$ \\
\hline
\end{tabular}

- Significant. decrease in heart rate in remifentanil group as compared with basal values. $(P<0.01)$.

- significant decrease in heart rate in remifentanil group as compared with saline and lidocaine groups. $(P<0.001)$.

\# significant. increase in heart rate in control and lidocaine groups as compared to basal values $(p<0.01)$.

Table (2) : mean blood pressure in saline, lidocaine and remifentanil groups from induction to $5 \mathrm{~min}$. after intubation (values are in mean).

\begin{tabular}{|c|c|c|c|}
\hline Time & Saline & Lidocaine & Remifentanil \\
\hline 0 & 96 & 89 & 89 \\
\hline (induction)1 & 87 & 85 & $66^{*} \bullet$ \\
\hline 2 & 85 & 80 & $62^{*} \bullet$ \\
\hline 3 & 80 & 78 & $59^{*} \bullet$ \\
\hline (intubation)1 & $117 \#$ & $103 \#$ & $62^{*} \bullet$ \\
\hline 2 & $104 \#$ & $100 \#$ & $65^{*} \bullet$ \\
\hline 3 & 94 & 92 & $66^{*} \cdot$ \\
\hline 4 & 87.5 & 85.5 & $66^{*} \bullet$ \\
\hline 5 & 79 & 77 & $62^{*} \bullet$ \\
\hline
\end{tabular}

* Significant. decrease in mean blood pressure in remifentanil group as compared to basal values. $(P<0.01)$.

- significant decrease in mean blood pressure in remifentanil group as compared with saline and lidocaine groups. $(P<0.001)$.

\# significant. increase in mean blood pressure in control and lidocaine groups as compared with basal values $(p<0.01)$.

Vol. 30 , No. 1 \& 2 Jan. \& April, 2000 


\section{DISCUSSION}

Hypertension and tachycardia usually accompany laryngoscopy and tracheal intubation (9). This undesirable response can be blunted by using lidocaine, opioids or inhaled anaesthetics(2). In our study lidocaine has been found to be ineffective in preventing cardiovascular changes associated with tracheal intubation, and there were increase in heart rate or mean blood pressure after laryngeoscopy and intubation, these results are in consistent with the study done by Helfman et al (1991) who found that $2.5 \mathrm{mg} / \mathrm{kg}$ lidocane $2 \mathrm{~min}$ before intubation failed to blunt the increase in both heart rate and blood pressure (10). Also, laurito etal (1988) who used $2 \mathrm{mg} / \mathrm{kg}$ lidocaine $1 \mathrm{~min}$ before intubation found that lidocaine was ineffective (4). In contrast to our study splinter et al (1989) reported that 1.5 $\mathrm{mg} / \mathrm{kg}$ lidocaine adminsterated $4 \mathrm{~min}$ before intubation attenuated hypertension but not tachycardia (6). The differences between the results of these studies may be due to difference in the dose or the time of injection of lidocaine before induction of anaesthesia.

In this present study, a bolus dose of remifentanil $1 \mathrm{ug} / \mathrm{kg}$ given over 30 second at induction of anaesthesia attenuated the haemodynamic response to endotracheal intubation; and there was a significant decrease in the mean blood pressure and the heart rate after induction of anaesthesia and remained lower after intubation as compared with basal values and non remifentanil treated groups. This result were in parellel with the work done by McAtamney and his collaegues(1998), who reported that after thiopental $5-7 \mathrm{mg} / \mathrm{kg}$ a bolus dose of remifentanil $1 \mathrm{ug} / \mathrm{kg}$ was effective in reducing the pressor response to intubation than $0.05 \mathrm{ug} / \mathrm{kg}$ and $0.25 \mathrm{ug} / \mathrm{kg}$ (11).Moreover, Ohare etal(1999) studied the effect of three bolus doses of remifentanil on the pressor response to laryngeoscopy and intubation in rapid sequence induction of anaesthesia and found that $1 \mathrm{ug} / \mathrm{kg}$ and $1.25 \mathrm{ug} / \mathrm{kg}$ doses were effective in controlling this response than $0.5 \mathrm{ug} /$ $\mathrm{kg}$ remifentanil(12). Thompson etal (1998) examined the effect of bolus dose $1 \mathrm{ug} / \mathrm{kg}$ of remifentanil followed by infusion of $0.5 \mathrm{ug} / \mathrm{kg}$ and reported that it attenuates the heamodynamic response to laryngeoscopy and intubation(13), however, Hall etal (2000) used $1 \mathrm{ug} / \mathrm{kg}$ and $0.5 \mathrm{ug} / \mathrm{kg}$ followed by $0.5 \mathrm{ug} / \mathrm{kg}$ and $0.25 \mathrm{ug} / \mathrm{kg}$ respectively and found that $0.5 \mathrm{ug} / \mathrm{kg}$

MANSOURA MEDICAL JOURNAL 
was ineffective in controlling pressor response(14).

Hypotention and bradycardia occur with remifentanil may require the use of vagolytic agents to minimize their incidence(13).

We can conclude that remifentanil is more effective than lidocaine in blunting the haemodynamic respose to laryngeoscopy and orotracheal intubation.

\section{REFERENCES}

1- Shribman AJ, Smith $G$ and Achola KJ (1987) : Cardiovascular and catecholamine response to laryngoscopy with and without endotracheal intubation. $\mathrm{Br}$. J. Anaesthesth; 59:295-299.

\section{2- Derbyshire DC, Chmielewski A,} Fell D, et al, (1983) : Plasma catecholamine response to tracheal intubation. Br. J. Anaesth; 55:855-859.

\section{3- Edwards DN, Alford AM, Dobson} P MS, et al (1994) : Myocardial ischemia during tracheal intubation and extubation. Br. J. Anaesth; 72:537-539.
4- Laurito C, B aughman V, Becker $G$, et al (1988): Effects of aerosolized and/or intravenous lidocaine on haemodynamic responses to laryngeoscopy and intubation in outpatients. Anaesth. Analg; 67:387-92.

5- King B, Harris L, Greitenstin F, et al (1951) : Reflex circulatory responses to direct laryngeascopy and tracheal intubation performed during general anaesthesia. Anesthiology; 12:55666. Coted from Helfman SM ,et al (1991): Wich drug prevents tachycardia and hypertention associated with tracheal intubation: Lidocaine, Fentanyl, or Esmolol?. Aneth. Analg.;72:182-6.

6- Splinter $W$ and cervenko $F$, (1989) : Haemody namic responses to laryngeoscopy and tracheal intubation in geriatric patients: effects of fentanyl, lidocaine and thiopentone. Can. J. Anaesth.; 36:370-6.

\section{7- Thompson JP and Rowbotham}

Vol. 30 , No. 1 \& 2 Jan. \& April, 2000 
DJ (1996) : Remifentanil- an opioid for the $21^{\text {st }}$ century. Br. J. Anaesth., 76:34-343.

8- Egan TD, Minto CF, Herman DJ, et al (1996) : Remifentanil versus alfentanil: Comparative pharmacokinetics and pharmacodynamics in heaIthy adult male volunteers. Anaesthesiology; 84:821833.

9- Prys-Roberts C, Greene L, Miloche R, et al (1984) : Studies of anaesthesia in relation to hypertemsion. Haemadynamic consequences of induction and endotracheal intubation. Br. J. Anaesth. ; 43:531-47.

10- Helfman SM, Gold MI, Delisser EA, et al (1991) : Which drug prevents Tachycardia and hypertension associated with tracheal intubation: lidocaine, Fentanyl/or Esmolol ? Anaesth. Analg.; 72: 182-6.

11- McAtamney D, ohare R,
Hughes D, et al (1998): Evaluation of remifentanil for control of haemodynamic response to tracheal intubation. Anaesthesia; 53:1223-7.

12- Ohare R, McAtamney D, Mirakhur RK, et al (1999) : Bolus dose remifentanil for control of haemodynamic response to tracheal intubation during rapid sequence induction of anaesthesia. $\mathrm{Br} . \mathrm{J}$. Anaesth.; 82:283-5.

13- Thompson JP, Hall AP, Cagney $B$ et al (1998) : Effect of remifentanil on haemodynamic response to orotracheal intubation. Br. J. Anaesth.; 80:467-469.

14- Hall AP, Thompson JP, Leslie NAP, et al (2000) : Comparison of different doses of remifentanil on cardiovascular response to laryngeoscopy and tracheal intubation. Br. J. Anaesth.; 84 (1) : 100-2. 
